\title{
MEDITACIÓN DEL HABITANTE
}

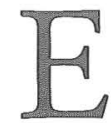

L RITO QUE RODEA LA presentación de un libro suele acotarse en dos apartados: esbozar algún perfil biográfico acerca del autor y señalar los relatos que configuran sus textos o bien discurrir por sus páginas tratando de descifrar y analizar las ideas y testimonios narrados por el autor de la obra.

Esta «parábola del vacío inocente de la ciudad», que el autor Carlos Castilla del Pino tituló como Meditación del babitante, me ha parecido más sugerente, aun alejándome de una precisa valoración crítica del libro, al discurrir por la secuencia de sus páginas y trasladar los testimonios que me suscita su lectura en el marco intelectual y biográfico de su autor.

Estos textos son testimonios invadidos, sin duda, por la mirada inteligente y despierta de un pensamiento crítico en el contexto del siglo precedente, junto a una tensión de duelo motivada por la situación de lo humano en el entorno de los acontecimientos que sucedieron en la ciudad moderna, y cómo a muchas mentes lucidas de estas generaciones les resulta difícil alejarse en sus trabajos de cierto aroma melancólico, o si prefieren de esa cadencia sintomática a ver las cosas bajo el signo de la perdida. Paráfrasis, la de estos textos dispersos y varios, recreados por las luces primeras de los rocíos, ideas sedimentadas con otros saberes, saberes disciplinados, ya experimentados al calor del crepúsculo de los años, meditación, en fin de recuerdos, memoria, miradas que se deslizan por el discurrir acelerado de su narración.

Estos apuntes del nómada ciudadano, Meditación del babitante que trasiega por nuestras sendas asfaltadas, vienen entrelazados 
con rasgos de cierto cansancio, de entumecida y altiva melancolía, de epitafios con sintaxis de sutil nostalgia, siempre recuperados por el autor, en presentes, de su activa y tenaz razón crítica. Su atención intelectual parece acentuarse, como en su larga y consagrada obra publicada, creo yo, en torno a la vieja sentencia de Anaximandro, «en el orden injusto del tiempo», que con tanto ardor describe en estos testimonios urbanos, en contraste con aquella capacidad de crear fantasía, vocación primaria de la ciudad, hasta que fue sitiada en su memoria y sus piedras.

Textos y testimonios escritos desde los argumentos de la razón crítica que de manera inequívoca evocan sus diferentes apartados y acotaciones junto a su decantado compromiso ético y teórico. Al fondo, y no como rasgo difuso, el diagnóstico sobre los valores perversos de la mercancía en los diferentes procesos de la construcción de la ciudad en su época; por otra parte, sustancia y nervio de la efeméride iconoclasta y de los vaivenes que acontecen en el territorio, la forma urbana y los escenarios que formaliza su arquitectura.

La lectura de sus páginas nos invita a conjugar una secuencia de verbos: evocar, recordar, rememorar o revivir, algo que sucedió en tiempos no muy lejanos, memoria al fin, estratificada en «pretéritos imaginarios» que el sujeto urbano reclamaba para habitar bien la ciudad, según los saberes de la estirpe aristotélica: la ciudad nace para la urgencia del vivir, pero subsiste para vivir bien.

El sumario de estas páginas nos muestra y define en rasgos muy precisos la invalidez y soledad que acompaña al habitante, ya en perfiles del sujeto posmoderno, abatido entre los desvaríos de la lógica de la mercancía, que le invade y coloniza, como digo, en los territorios más próximos y, en las aspiraciones y los sentimientos de un bumanismo moral que no acaba muy bien de controlar. Ambigüedad que perturba su estar apacible o desgarrado en la ciudad y, como diagnostica el autor, «les altera el sujeton; la mentira, entonces, no resulta ser la falsificación de un dato, de un hecho... sino de ellos mismos en su totalidad (pág. 29).

No es de extrañar que un analista riguroso, como fue el de tan señalado doctor en psiquiatría, recurra al refugio privado de «la casa del olivo en los llanos». ¿No asume, acaso, esta bella 
paráfrasis el contenido de una fábula?, describiendo los lugares, sitios y recodos del inocente vacío del espacio que construye la arquitectura de la ciudad: oikos, termino para los griegos que definía la casa como el lugar que ha de funcionar como principio y fin del habitar, se desborda por las paginas acotadas de estos textos de apomazada sabiduría ciudadana.

El segundo apartado que nos ofrece la edición se organiza bajo el título de «Aproximaciones», textos y testimonios en torno a la década de los setenta: la destrucción del patrimonio monumental, la degradación de la ciudad de Córdoba, el monumento urbano, Andalucía, la mirada del paisaje. Estos escritos nos desvelan desde el cotidiano deambular por sus calles, ámbitos y recintos, cómo la ciudad de nuestra memoria, desacralizado el tiempo y transformado el espacio urbano en producto simbólico de la mercancía, se ha transformado en su conjunto en un paisaje desolador después de los festivales de la voracidad especulativa.

Desde entonces, el libro nos descubre - anota su autorcómo la ciudad que nos acompaña en su crecimiento es una espacialidad en algunos de sus recintos indigente de sentido, depresiva en sus relaciones urbanas, junto a la escena de una arquitectura que se construye en inestables caligrafías más o menos erudita, como tan bien queda reflejada en la levedad del muro de sus edificios, mientras sus fábricas agonizan por el simulacro edificatorio.

Meditación del babitante no puede eludir, ser, un testimonio de despedida; dudas, miradas, visiones, anhelos, ventura que ha sido todo el tiempo vivido por el autor; contraciertos y sinfortunas, hallazgos y beligerantes esbozos. Todo recogido en una narración próxima a las contradicciones más hirientes de la evolución de la polis en los espacios contemporáneos que la han edificado. Apunta una aguda crítica al relativismo nihilista posmoderno y acentúa, como ya he señalado, el desencanto que ha producido la pretensión totalizadora de la polis como producto de mercado, sin dejar de advertirnos de los peligros que encierra un pensamiento cautivo por la incontrolada soberbia tecnocrática.

En definitiva, el agotamiento de un modelo económico y las correspondientes formas de intuir el proyecto y construcción del espacio de la ciudad. La lectura de sus páginas nos deja 
un rescoldo de melancolía frente a los espacios de la ciudad nueva de imágenes y arquetipos, de conceptos y ficciones platónicas que los apologetas de la nueva economía nos anuncian en gráficos y mapas del bienestar, en esa trama globalizada en la que los nómadas telemáticos de las nuevas ciudades se disiparán en las tecnologías de relación con digitales tarjetas de prolongada esperanza de vida y la oferta publicitaria de los mil productos y renovación de servicios en los que disipará su vida la meditación del habitante. 